\title{
Evaluasi Perencanaan dan Distribusi Obat Program di Dinas Kesehatan Provinsi Sulawesi Tenggara
}

\author{
Evaluation of Drug Program Planning and Distribution in Southeast Sulawesi Province Health Office
}

\author{
Yuliana Boku ${ }^{1 *}$, Satibi ${ }^{2}$, Nanang Munif Yasin ${ }^{2}$ \\ 1. Program Pasca Sarjana, Program Studi IImu Farmasi, Fakultas Farmasi, Universitas Gadjah Mada \\ 2. Fakultas Farmasi, Universitas Gadjah Mada \\ Submitted: 23-01-2019 Revised: 21-03-2019 \\ Korespondensi : Yuliana Boku : Email : yulianaboku3@gmail.com \\ Accepted: 20-06-2019
}

\begin{abstract}
ABSTRAK
Pembangunan bidang kesehatan menjadi perhatian penting dalam komitmen internasional yang dituang dalam Millenium Development Goals (MDGs). Salah satu indikatornya adalah ketersediaan dan keterjangkauan obat, sehingga diperlukan manajemen pengelolaan obat yang baik. Tujuan Penelitian ini untuk mengetahui perencanaan dan distribusi obat program tahun 2017 di Dinas Kesehatan Provinsi Sulawesi Tenggara serta faktor-faktor yang mempengaruhinya. Penelitian ini dilakukan pada bulan September - Oktober 2018. Obat program yang dievaluasi adalah malaria, kusta, tuberkulosis dan Humman Immunodeficiency Virus (HIV)/ Acquired Immunodeficiency Syndrome (AIDS). Penelitian ini bersifat deskriptif dengan data kuantitatif yang diperoleh secara retrospektif dan data kualitatif yang diperoleh melalui observasi dan wawancara dengan narasumber yang dipilih secara purposive sampling. Data yang diperoleh dianalisis menggunakan indikator dan dibandingkan dengan hasil penelitian. Hasil penelitian menunjukkan bahwa perencanaan dan distribusi obat program di Dinas Kesehatan Provinsi Sulawesi Tenggara belum sepenuhnya memenuhi standar indikator. Hal ini ditunjukkan dengan 8 indikator belum memenuhi standar, yaitu ketepatan perencanan; penyimpangan perencanaan; tingkat ketersediaan obat; persentase obat kadaluarsa; persentase penyimpangan obat yang didistribusikan; Inventory Turn Over Ratio (ITOR); rata-rata waktu kekosongan obat; persentase stok obat mati dan 7 indikator sudah memenuhi standar, yaitu sistem penataan obat; kecocokan jumlah barang nyata dengan stok; manajemen organisasi; penanggung jawab; jumlah sumber daya manusia; keuangan dan sistem informasi. Faktor-faktor yang mempengaruhi, yaitu koordinasi Tim; pencatatan dan pelaporan; realisasi dana operasional.
\end{abstract}

Kata kunci: Evaluasi, perencanaan, distribusi, obat program.

\begin{abstract}
The development of the health sector is an important concern in the international commitments set out in the Millennium Development Goals (MDGs). One of the indicators is the availability and affordability of drugs. Therefore, good management of drugs is needed. This study aims to evaluate planning and distribution of drug programs in 2017 at the Southeast Sulawesi Provincial Health Office and the factors that influence it. This study was conducted in September - October 2018. The programs' drugs evaluated were for malaria, leprosy, tuberculosis and Human Immunodeficiency Virus (HIV)/Acquired Immunodeficiency Syndrome (AIDS). This is a descriptive research with quantitative data obtained retrospectively and qualitative data obtained through observations and interviews with interviewees selected by purposive sampling. The data was analyzed using indicators and then compared with the research results. The results showed that the planning and distribution of the drugs had not been fully in accordance with the standard. It was indicated that there were 8 indicators had not meet the standards, namely the accuracy of planning; planning irregularities; level of drug availability; percentage of drugs expired; percentage of deviations from drugs distributed; Inventory Turn Over Ratio (ITOR); average time of drug emptiness; the percentage of dead drug stock, and there were 7 indicators which had met the standard, namely the drug structuring system; the matching number of real goods with stock; organizational management; responsible person; the number of human resources; and financial and information systems. The factors that influence is team coordination; recording and reporting; and operational funds.
\end{abstract}

Keywords: Evaluation, planning, distribution, drug programs. 


\section{PENDAHULUAN}

Pembangunan bidang kesehatan menjadi perhatian penting dalam komitmen internasional yang dituang dalam Millenium Development Goals (MDGs) yang salah satu tujuannya adalah memerangi penyakit menular. Keputusan menteri kesehatan nomor 1457/2003 tentang standar pelayanan minimal (SPM) menyebutkan bahwa salah satu indikator pengadaan obat esensial dan obat generik sebesar $100 \%$. Indikator lainnya adalah program pencegahan dan pemberantasan penyakit menular membutuhkan ketersediaan dan keterjangkauan obat $^{1}$. Untuk menjamin ketersediaan, pemerataan dan keterjangkauan obat, diperlukan manajemen pengelolaan obat yang baik meliputi tahap seleksi, pengadaan, distribusi dan penggunaan, serta didukung oleh pendukung manajemen yang meliputi manajemen organisasi, ketersediaan dana pengadaan obat dan operasional lainnya, penanggung jawab, jumlah SDM dan sistem informasi².

Permasalahan umum yang terkait dengan obat ARV yang berasal dari donor atau pinjaman hibah luar negeri adalah sistem dan prioritas yang cenderung diarahkan oleh donor, prosedur yang merepotkan, kurang koordinasi, negosiasi dengan donor yamg berbeda, adanya kebutuhan yang mendadak dalam jumlah yang banyak terhadap suatu produk, mekanisme pendanaan berbeda serta keterlambatan dalam pelaporan dan pembayaran ${ }^{3}$. Salah satu sumber pendanaan pengelolaan beberapa obat program yaitu obat program malaria, kusta, tuberkulosis (TB) dan Humman Immunodeficiency Virus (HIV)/ Acquired Immunodeficiency Syndrome (AIDS) di Dinas Kesehatan Provinsi Sulawesi Tenggara berasal dari donor atau pinjaman hibah luar negeri.

Unit Pelaksana Teknis Dinas (UPTD) Balai Pengelola Farmasi dan Perbekalan Kesehatan sebagai salah satu Unit Pelaksana Teknis Dinas Kesehatan Provinsi Sulawesi Tenggara memiliki tugas melaksanakan pengelolaan obat dan perbekalan kesehatan satu pintu (one gate policy). Beberapa permasalahan yang dihadapi terkait pengelolaan obat terutama obat program, yaitu terjadinya kekosongan obat, obat berlebih dan obat kadaluarsa. Hal ini dapat mengganggu upaya pelayanan kesehatan, ketersediaan dan keterjangkauan obat serta dapat meningkatkan prevalensi penyakit menular, sehingga perlu dilakukan Evaluasi Perencanaan dan Distribusi Obat Program di Dinas Kesehatan Provinsi Sulawesi Tenggara. Penelitian terkait evaluasi pengelolan obat sudah banyak dilakukan seperti Rumah Sakit $^{4,5,6,7,}$, puskesmas ${ }^{8}$ dan Dinas Kesehatan ${ }^{9}{ }^{10}$. Perbedaan penelitian ini dengan penelitian pengelolaan obat sebelumnya terdapat pada variabel penelitian, penelitian ini menggunakan variabel pada tahap perencanaan dan distribusi obat program penyakit menular yang fast moving meliputi program malaria, kusta, TB dan HIV/ AIDS. Pemilihan variabel ini berdasarkan pada tahap pengelolaan obat yang dilakukan di Dinas Kesehatan Provinsi Sulawesi Tenggara, yaitu tahap perencanaan dan distribusi. Tujuan Penelitian ini untuk mengetahui gambaran perencanaan dan distribusi obat program tahun 2017 di Dinas Kesehatan Provinsi Sulawesi Tenggara serta faktor-faktor yang mempengaruhinya.

\section{METODE}

Penelitian ini dilakukan di Dinas Kesehatan Provinsi Sulawesi Tenggara pada bulan September-Oktober 2018 dan bersifat deskriptif. Penelitian ini disetujui oleh Komite Etik Penelitian Medis dan Kesehatan (MHREC) Fakuktas Kedokteran Universitas Gadjah Mada-Rumah Sakit Umum Dr. Sardjito Yogyakarta dengan nomor sertifikat $\mathrm{KE} / \mathrm{FK} / 1068 / \mathrm{EC} / 2018$, tanggal 11 Oktober 2018. Evaluasi dilakukan pada tahap perencanaan dan distribusi terhadap obat program yang memiliki kriteria inklusi, yaitu obat pengendalian penularan penyakit menular yang salah satu sumber dananya berasal dari donor atau pinjaman hibah luar negeri, fast moving dan dikelola oleh UPTD Balai Pengelola Farmasi dan Perbekalan Kesehatan selama tahun 2017, maka obat 
program yang diteliti adalah obat program malaria sebanyak 7 item obat, TB sebanyak 4 item obat, Kusta 7 item obat dan HIV/AIDS 18 item obat. Jumlah item obat yang diteliti untuk tiap jenis obat program disesuaikan dengan jumlah item obat perencanaan dan pendistribusian yang dilakukan di Dinas Kesehatan Provinsi Sulawesi Tengara.

Metode yang digunakan adalah pengumpulan data, observasi dan wawancara. Pengumpulan data dilakukan secara retrospektif melalui penelusuran data dokumen perencanaan dan distribusi obat program tahun 2017. Observasi dilakukan terhadap faktor-faktor yang mempengaruhi perencanaan dan distribusi dengan menggunakan daftar tilik, sedangkan wawancara dilakukan oleh peneliti secara mendalam dengan menggunakan pedoman wawancara dan alat perekam pada bulan September-Oktober 2018 terhadap narasumber yang dipilih secara purposive sampling, yaitu pemilihan narasumber dengan pertimbangan bahwa narasumber dianggap paling mengetahui dan bertanggung jawab terhadap pengelolaan obat program di Dinas Kesehatan Provinsi Sulawesi Tenggara. Narasumber yang dipilih adalah Kepala Seksi Farmasi, Kepala Seksi Pengendalian Penyakit Menular dan bersumber binatang, Kepala Seksi Pengelola Farmasi dan Perbekkes, Kepala Seksi distribusi Farmasi dan Perbekkes, Wakil supervisor (Wasor) Program malaria, Wasor Program TB, Wasor Program kusta, Wasor Program HIV/AIDS, Petugas Pengelola RKO dan Petugas Pengelola Obat Program.

Data hasil penelitian berupa data kuantitatif dan kualitatif. Data kuantitatif diperoleh melalui penelusuran data dokumen perencanaan dan distribusi obat program tahun 2017 yang berupa Rencana Kebutuhan Obat (RKO), Dokumen penerimaan obat, surat permintaan obat program, Surat Bukti Barang Keluar (SBBK), Berita Acara Serah Terima (BAST) dan kartu stok, kemudian dihitung menggunakan analyze frequencies dan hasil yang diperoleh dibandingkan dengan nilai standar indikator sesuai (Tabel I). Indikator yang digunakan merupakan indikator yang ada di Dinas kesehatan dan Rumah sakit karena perencanaan obat program yang dilakukan oleh Wasor Dinas Kesehatan Provinsi Sulawesi Tenggara bertujuan untuk memenuhi kebutuhan Instalasi Farmasi Kota/ Kabupaten dan Rumah Sakit di Wilayah Provinsi Sulawesi Tenggara dan pendistribusian obat program dilakukan ke Instalasi Farmasi Kota/ Kabupaten dan Rumah Sakit di Wilayah Provinsi Sulawesi Tenggara. Data kualitatif diperoleh dari hasil wawancara yang direkam kemudian dibuat dalam versi tertulis dan dibandingkan dengan hasil observasi, selanjutnya data kualitatif digunakan untuk mengetahui faktor-faktor yang mempengaruhi perencanaan dan pendistribusian obat program. Penyajian hasil analisis data kuantitatif berupa tabel, sedangkan analisis data kualitatif dalam bentuk narasi.

\section{HASIL DAN PEMBAHASAN Perencanaan}

Indikator yang digunakan adalah ketepatan perencanaan dan penyimpangan perencanaan.

\section{Ketepatan perencanaan}

Ketepatan perencanaan merupakan jumlah tiap item obat yang direncanakan dibagi dengan jumlah pemakaian setahun. Hasil yang diperoleh adalah $6,1 \%$ sesuai (Tabel II). Nilai standar yang digunakan adalah $100-150 \%{ }^{11}$. Jika dibandingkan dengan nilai standar, maka hasil penelitian ini belum memenuhi standar. Hasil penelitian ini masih belum lebih baik dari hasil penelitian ${ }^{4,15,16}$, yaitu $72,3 \%$, 50\% dan 105,01\%. Hal ini dikarenakan obat yang diterima tidak sesuai dengan yang direncanakan, adanya obat dropping, penerimaan obat diakhir tahun, data pemakaian yang kurang akurat dan perubahan pola pengobatan penyakit. Penelitian sebelumnya juga menyebutkan bahwa perencanaan yang kurang tepat dikarenakan kurang memperhatikan stok dan memprediksi perkembangan pola penyakit ${ }^{8}$. 
Yuliana Boku, et al

Tabel I. Indikator Efektifitas dan Efisiensi Pengelolaan Obat Program

\begin{tabular}{|c|c|c|}
\hline Tahap & Indikator & Nilai standar \\
\hline \multirow[t]{2}{*}{ Perencanaan } & Ketepatan perencanaan & $100 \%-150 \%{ }^{11}$ \\
\hline & Persentase Penyimpangan perencanaan & $20-30 \%{ }^{12}$ \\
\hline \multirow{8}{*}{$\begin{array}{l}\text { Distribusi dan } \\
\text { penyimpanan }\end{array}$} & Tingkat ketersediaan obat & $12-18$ bulan $^{12}$ \\
\hline & $\begin{array}{l}\text { Persentase jumlah dan nilai obat yang } \\
\text { kadaluarsa/rusak }\end{array}$ & $\leq 2 \%$ dalam setahun ${ }^{1}$ \\
\hline & $\begin{array}{l}\text { Persentase penyimpangan jumlah obat } \\
\text { yang didistribusikan }\end{array}$ & $0 \%$ \\
\hline & $\begin{array}{l}\text { Persentase rata-rata waktu kekosongan } \\
\text { obat }\end{array}$ & 10 hari $^{2}$ \\
\hline & Persentase stok obat yang mati & $0 \% 12$ \\
\hline & ITOR & $8-12$ kali/tahun ${ }^{12}$ \\
\hline & Sistem penataan obat & Sesuai FEFO/ FIFO ${ }^{11}$ \\
\hline & $\begin{array}{l}\text { Persentase kecocokan jumlah barang } \\
\text { nyata dengan kartu stok }\end{array}$ & $100 \%{ }^{12}$ \\
\hline \multirow{5}{*}{$\begin{array}{l}\text { Pendukung } \\
\text { manajemen terhadap } \\
\text { perencanaan dan } \\
\text { distribusi }\end{array}$} & Manajemen organisasi & $\begin{array}{l}\text { Berjenjang pusat, } \\
\text { Provinsi, Kota/ } \\
\text { Kabupaten }^{13}\end{array}$ \\
\hline & $\begin{array}{l}\text { Ketersediaan dana pengadaan obat dan } \\
\text { operasional lainnya }\end{array}$ & Tersedia $^{1}$ \\
\hline & Penangung jawab & $\begin{array}{l}\text { Apoteker atau tenaga } \\
\text { farmasi }^{1}\end{array}$ \\
\hline & Jumlah SDM & $\geq 4$ orang 14 \\
\hline & Sistem informasi & Tersedia $^{1}$ \\
\hline
\end{tabular}

Tabel II. Ketepatan Perencanaan

\begin{tabular}{|c|c|c|c|c|c|c|c|c|c|}
\hline \multirow{3}{*}{$\begin{array}{c}\text { Jenis obat } \\
\text { program }\end{array}$} & \multirow{3}{*}{$\begin{array}{c}\Sigma \\
\text { item } \\
\text { obat }\end{array}$} & \multicolumn{8}{|c|}{ Pengelompokkan ketepatan perencanaan item obat } \\
\hline & & \multicolumn{2}{|c|}{$\begin{array}{c}\text { Kurang } \\
(<100)\end{array}$} & \multicolumn{2}{|c|}{$\begin{array}{c}\text { Tepat } \\
(100-150)\end{array}$} & \multicolumn{2}{|c|}{$\begin{array}{c}\text { Berlebih } \\
(>150)\end{array}$} & \multicolumn{2}{|c|}{$\begin{array}{c}\text { Tidak } \\
\text { teridentifikasi } \\
(\infty)\end{array}$} \\
\hline & & $\Sigma$ obat & $\%$ & $\Sigma$ obat & $\%$ & $\Sigma$ obat & $\%$ & $\Sigma$ obat & $\%$ \\
\hline Malaria & 6,0 & 4,0 & 66,7 & 0,0 & 0,0 & 2,0 & 33,3 & 0,0 & 0,0 \\
\hline Kusta & 6,0 & 3,0 & 50,0 & 1,0 & 16,7 & 0,0 & 0,0 & 2,0 & 33,3 \\
\hline TB & 5,0 & 3,0 & 60,0 & 0,0 & 0,0 & 1,0 & 20,0 & 1,0 & 20,0 \\
\hline HIV/ AIDS & 13,0 & 10,0 & 76,9 & 1,0 & 7,7 & 2,0 & 15,4 & 0,0 & 0,0 \\
\hline \multicolumn{2}{|c|}{ Rata-rata (\%) } & & 63,4 & & 6,1 & & 17,2 & & 13,3 \\
\hline
\end{tabular}

Persentase penyimpangan perencanaan

Persentase penyimpangan perencanaan adalah persentase penjumlahan stok awal dan rencana pengadaan tiap item obat dikurangi pemakaian tiap item obat dalam setahun kemudian dibagi dengan penjumlahan stok awal dan rencana pengadaan tiap item obat. Nilai standar persentase penyimpangan perencanaan adalah $20-30 \%{ }^{12}$. Tabel III menunjukkan hasil persentase penyimpangan perencanaan, yaitu 5,85\%. Jika dibandingkan dengan nilai standar maka penyimpangan perencanaan di Dinas Kesehatan Provinsi Sulawesi Tenggara belum memenuhi standar. Hasil penelitian ini belum lebih baik dari hasil penelitian $^{5}$ adalah 9,15\%. Hal ini disebabkan oleh ketidaktepatan perencanaan dan perubahan pola penyakit. 
Tabel III. Persentase Penyimpangan Perencanaan

\begin{tabular}{|c|c|c|c|c|c|c|c|c|c|}
\hline \multirow{3}{*}{$\begin{array}{c}\text { Jenis obat } \\
\text { program }\end{array}$} & \multirow{3}{*}{$\begin{array}{c}\Sigma \\
\text { item } \\
\text { obat }\end{array}$} & \multicolumn{8}{|c|}{ Pengelempokkan penyimpangan perencanaan item obat } \\
\hline & & \multicolumn{2}{|c|}{$\begin{array}{c}\text { Kurang } \\
(<20)\end{array}$} & \multicolumn{2}{|c|}{$\begin{array}{l}\text { Tepat } \\
(20-30)\end{array}$} & \multicolumn{2}{|c|}{$\begin{array}{c}\text { Berlebih } \\
\quad(>30)\end{array}$} & \multicolumn{2}{|c|}{$\begin{array}{c}\text { Tidak } \\
\text { teridentifikasi } \\
(\infty)\end{array}$} \\
\hline & & $\Sigma$ obat & $\%$ & $\Sigma$ obat & $\%$ & $\Sigma$ obat & $\%$ & $\Sigma$ obat & $\%$ \\
\hline Malaria & 7,0 & 1,0 & 14,3 & 0,0 & 0,0 & 6,0 & 85,7 & 0,0 & 0,0 \\
\hline Kusta & 6,0 & 0,0 & 0,0 & 1,0 & 16,7 & 5,0 & 83,3 & 0,0 & 0,0 \\
\hline TB & 5,0 & 3,0 & 60,0 & 0,0 & 0,0 & 2,0 & 40,0 & 0,0 & 0,0 \\
\hline HIV/ AIDS & 15,0 & 5,0 & 33,3 & 1,0 & 6,7 & 6,0 & 40,0 & 3,0 & 20,0 \\
\hline \multicolumn{2}{|c|}{ Rata-rata (\%) } & & 26,9 & & 5,85 & & 62,25 & & 5,0 \\
\hline
\end{tabular}

Tabel IV. Tingkat Ketersediaan Obat

\begin{tabular}{|c|c|c|c|c|c|c|c|c|c|c|c|}
\hline \multirow{3}{*}{$\begin{array}{c}\text { Jenis } \\
\text { obat } \\
\text { program }\end{array}$} & \multirow{3}{*}{$\begin{array}{c}\Sigma \\
\text { item } \\
\text { obat }\end{array}$} & \multicolumn{10}{|c|}{ Pengelompokkan tingkat ketersediaan item obat } \\
\hline & & \multicolumn{2}{|c|}{$\begin{array}{c}\text { Kosong } \\
(=0)\end{array}$} & \multicolumn{2}{|c|}{$\begin{array}{c}\text { Kurang } \\
(0-12)\end{array}$} & \multicolumn{2}{|c|}{$\begin{array}{l}\text { Aman } \\
(12-18)\end{array}$} & \multicolumn{2}{|c|}{$\begin{array}{c}\text { Berlebih } \\
(>18)\end{array}$} & \multicolumn{2}{|c|}{$\begin{array}{c}\text { Tidak } \\
\text { teridentifikas } \\
(\infty)\end{array}$} \\
\hline & & $\begin{array}{c}\Sigma \\
\text { obat }\end{array}$ & Bulan & $\begin{array}{c}\Sigma \\
\text { obat }\end{array}$ & Bulan & $\begin{array}{c}\Sigma \\
\text { obat }\end{array}$ & Bulan & $\begin{array}{c}\Sigma \\
\text { obat }\end{array}$ & Bulan & $\begin{array}{c}\Sigma \\
\text { obat }\end{array}$ & Bulan \\
\hline Malaria & 7,0 & 0,0 & 0,0 & 0,0 & 0,0 & 2,0 & 28,6 & 4,0 & 57,1 & 1,0 & 14,29 \\
\hline Kusta & 7,0 & 0,0 & 0,0 & 0,0 & 0,0 & 2,0 & 28,6 & 2,0 & 28,6 & 3,0 & 42,9 \\
\hline TB & 4,0 & 0,0 & 0,0 & 0,0 & 0,0 & 2,0 & 50,0 & 2,0 & 50,0 & 0,0 & 0,0 \\
\hline $\begin{array}{l}\text { HIV/ } \\
\text { AIDS }\end{array}$ & 18,0 & 0,0 & 0,0 & 0,0 & 0,0 & 1,0 & 5,6 & 12,0 & 66,7 & 5,0 & 27,8 \\
\hline \multicolumn{3}{|c|}{ Rata-rata (bulan) } & 0,0 & & 0,0 & & 28,2 & & 50,6 & & 21,2 \\
\hline
\end{tabular}

\section{Penyimpanan dan pendistribusian}

Indikator yang digunakan dalam tahap penyimpanan dan pendistribusian adalah tingkat ketersediaan, persentase dan nilai obat kadaluarsa, persentase jumlah obat yang didistribusikan, persentase rata-rata waktu kekosongan obat, stok obat mati, ITOR, Sistem penyimpanan obat dan Persentase kecocokan jumlah barang nyata dengan kartu stok.

\section{Tingkat ketersediaan obat}

Tingkat ketersediaan obat adalah jumlah tiap item obat yang tersedia dibagi rata-rata pemakaian tiap item obat per bulan. Pengukuran tingkat ketersediaan obat di UPTD Balai Pengelola Farmasi dan Perbekalan Kesehatan (Tabel IV) adalah 28,2 bulan. Hal ini menunjukkan tingkat ketersediaan di Dinas Kesehatan Provinsi Sulawesi Tenggara belum memenuhi standar, yaitu 12-18 bulan ${ }^{12}$, sehingga akan mengakibatkan tidak terpenuhinya kebutuhan obat program untuk pelayanan kesehatan. Hasil penelitian ini belum lebih baik jika dibandingkan dengan hasil penelitian ${ }^{8}$ sebesar 13,05 bulan. Hal ini dikarenakan jumlah pemakaian obat yang lebih kecil dari jumlah obat yang tersedia dan adanya perubahan pola pengobatan penyakit.

\section{Persentase jumlah dan nilai obat yang kadaluarsa}

Persentase jumlah obat yang kadaluarsa adalah persentase jumlah item obat yang kadaluarsa dalam satu tahun dibagi jumlah item obat yang tersedia dalam satu tahun. Nilai obat yang kadaluarsa merupakan jumlah obat yang kadaluarsa dikali harga obat. Hasil penelitian pada (Tabel V) menunjukkan bahwa persentase jumlah obat yang kadaluarsa adalah $8,33 \%$ dari total 36 item obat yang tersedia senilai Rp. 1.890.395. Hasil ini lebih besar dari nilai standar yang 
Yuliana Boku, et al

Tabel V. Persentase Jumlah dan Nilai Obat yang Kadaluarsa

\begin{tabular}{llllll}
\hline $\begin{array}{c}\text { Jenis obat } \\
\text { Program }\end{array}$ & Nama item obat & Satuan & $\begin{array}{c}\boldsymbol{\Sigma} \text { tiap item } \\
\text { obat yang } \\
\text { kadaluarsa }\end{array}$ & Harga (Rp) & $\begin{array}{l}\text { Nilai obat yang } \\
\text { kadaluarsa (Rp) }\end{array}$ \\
\hline Malaria & Quinine injeksi & Ampul & 25 & 5.706 & 142.650 \\
Malaria & Doxycycline & Kapsul & 3.100 & 257 & 796.700 \\
TB & OAT combipac & Paket & 3 & 317.015 & 951.045 \\
Total & & & & & \\
\hline
\end{tabular}

Tabel VI. Persentase Penyimpangan Jumlah Obat yang Didistribusikan

\begin{tabular}{|c|c|c|c|c|c|c|c|}
\hline \multirow{3}{*}{$\begin{array}{l}\text { Jenis obat } \\
\text { program }\end{array}$} & \multirow{3}{*}{$\begin{array}{l}\Sigma \text { item } \\
\text { obat }\end{array}$} & \multicolumn{6}{|c|}{ Pengelompokkan Penyimpangan pendistribusian item obat } \\
\hline & & \multicolumn{2}{|c|}{$\begin{array}{c}\text { Kurang } \\
(<0)\end{array}$} & \multicolumn{2}{|c|}{$\begin{array}{c}\text { Tepat } \\
(=0)\end{array}$} & \multicolumn{2}{|c|}{$\begin{array}{c}\text { Berlebih } \\
(>0)\end{array}$} \\
\hline & & $\Sigma$ obat & $\%$ & $\Sigma$ obat & $\%$ & $\Sigma$ obat & $\%$ \\
\hline Malaria & 7,0 & 2,0 & 28,6 & 0,0 & 0,0 & 5,0 & 71,4 \\
\hline Kusta & 5,0 & 0,0 & 0,0 & 0,0 & 0,0 & 5,0 & 100,0 \\
\hline $\mathrm{TB}$ & 4,0 & 0,0 & 0,0 & 0,0 & 0,0 & 4,0 & 100,0 \\
\hline HIV/AIDS & 13,0 & 0,0 & 0,0 & 1,0 & 7,7 & 12,0 & 92,3 \\
\hline \multicolumn{3}{|c|}{ Rata-rata (\%) } & 7,2 & & 1,9 & & 90,9 \\
\hline
\end{tabular}

ditetapkan, yaitu $\leq 2 \% 1$. Hasil penelitian ini masih belum lebih baik dari hasil penelitian $^{9,17,18,19}$ sebesar 1,57\%, 0,3\%, 7,01\% dan $0,5 \%$, sehingga akan mengakibatkan kerugian bagi Negara. Hal ini disebabkan karena adanya perubahan pola penyakit dan tidak adanya permintaan dalam rentang waktu tertentu.

\section{Persentase penyimpangan jumlah obat yang didistribusikan}

Persentase penyimpangan jumlah obat yang didistribusikan adalah persentase jumlah tiap item obat yang diminta dibagi jumah pemberian tiap item obat dari gudang. Nilai standar persentase penyimpangan jumlah obat yang didistribusikan menurut ${ }^{11}$ adalah $0 \%$. Tabel VI menunjukkan hasil persentase penyimpangan jumlah obat yang didistribusikan, yaitu 1,9\% dengan interval nilai yang kecil pada obat program kusta, TB dan HIV/AIDS. Jika dibandingkan dengan nilai standar maka hasil penelitian belum memenuhi standar, sehingga akan mengganggu pelayanan kesehatan. Hal ini disebabkan pemberian obat dari UPTD Balai
Pengelola Farmasi dan Perbekalan Kesehatan disesuaikan dengan verifikasi washor dan ketersediaan obat. Hasil penelitian ${ }^{20}$ menyebutkan bahwa pendistribusian obat program merupakan tanggung jawab Wasor, instalasi Farmasi Kota/Kabupaten maupun Provinsi berperan sebagai fasilitator.

\section{Persentase rata-rata waktu kekosongan obat}

Persentase rata-rata waktu kekosongan obat merupakan persentase jumlah hari kekosongan obat dalam satu tahun. Jumlah hari kekosongan obat sesuai (Tabel VII) adalah 1.094 terhadap 36 item obat, sehingga rata-rata waktu kekosongan obat yang diperoleh adalah 30 hari dengan persentase sebesar 8,33\%. Apabila dibandingkan dengan nilai standar ideal rata-rata waktu kekosongan obat menurut ${ }^{2}$, yaitu 10 hari maka hasil yang diperoleh melebihi nilai standar. Hasil penelitian ini belum lebih baik dari hasil penelitian', yaitu 9 hari, sehingga akan menganggu kesinambungan suplai obat. Hal ini dikarenakan adanya perubahan pola penyakit, obat yang diterima lebih sedikit dari 
Tabel VII. Persentase Rata-rata Waktu Kekosongan Obat

\begin{tabular}{llc}
\hline Jenis obat Program & Nama item obat & $\boldsymbol{\Sigma}$ hari kekosongan item obat \\
\hline Malaria & Quinine injeksi & 184 \\
Malaria & Arthemeter injeksi & 138 \\
Malaria & Doxycycline & 92 \\
Kusta & MB-Anak & 9 \\
Kusta & PB-Anak & 126 \\
Kusta & Lamprene & 365 \\
TB & OAT kategori II FDC & 119 \\
TB & OAT combipac & 61 \\
& Total & $\mathbf{1 . 0 9 4}$ \\
\hline
\end{tabular}

Tabel VIII. Stok Obat Mati

\begin{tabular}{|c|c|c|c|c|c|}
\hline $\begin{array}{c}\text { Jenis obat } \\
\text { program }\end{array}$ & Nama item obat & Satuan & $\begin{array}{c}\Sigma \text { stok } \\
\text { obat mati }\end{array}$ & Harga (Rp) & $\begin{array}{c}\text { Nilai stok obat } \\
\text { mati (Rp) }\end{array}$ \\
\hline Malaria & Quinine injeksi & Ampul & 25 & 5.707 & 142.675 \\
\hline Kusta & Rifampicin $300 \mathrm{mg}$ & Tablet & 4.600 & 609 & 2.801 .400 \\
\hline Kusta & Rifampicin $450 \mathrm{mg}$ & Tablet & 7.400 & 790 & 5.846 .000 \\
\hline Kusta & Rifampicin $600 \mathrm{mg}$ & Tablet & 18.200 & 1.114 & 20.274 .800 \\
\hline HIV/AIDS & $\mathrm{ZDV}+3 \mathrm{TC}+\mathrm{NVP}$ & Tablet & 720 & 720 & 518.400 \\
\hline HIV/AIDS & $\begin{array}{l}\text { Lopinavir/ riyonavir } \\
\text { (200/500 mg) }\end{array}$ & Tablet & 2.880 & 4.668 & 13.443 .840 \\
\hline HIV/AIDS & Rilpivirine $25 \mathrm{mg}$ & Tablet & 720 & 3.091 & 2.225 .520 \\
\hline HIV/AIDS & Abacavir & Tablet & 720 & 7.596 & 5.469 .120 \\
\hline HIV/AIDS & Pyrimetamine & Tablet & 1596 & 1.996 & 3.185 .616 \\
\hline \multicolumn{5}{|c|}{ Total } & 53.907.371 \\
\hline
\end{tabular}

yang direncanakan dan keterlambatan pendistribusian obat dari pusat.

\section{Persentase stok obat mati}

Persentase stok obat mati diperoleh dari persentase jumlah item obat yang tidak pernah digunakan selama satu tahun dibagi dengan jumlah persediaan item obat selama satu tahun. Hasil yang diperoleh (Tabel VIII) adalah $25 \%$ terhadap 36 jenis obat yang tersedia dengan nilai stok obat mati, yaitu Rp 53.907.371, jika dibandingkan dengan nilai indikator menurut 12 yaitu sebesar $0 \%$ maka nilai hasil penelitian lebih besar dari nilai standar. Hal ini menunjukkan bahwa pengelolaan obat belum efisien. Hasil penelitian ini masih belum lebih baik dari hasil penelitian $^{6}$, yaitu 3,33\% tetapi lebih baik dari penelitian $^{21}$, yaitu 39\%. Hal ini dikarenakan adanya perubahan pola penyakit, obat dropping dari pusat dan belum ada peraturan tentang penggunaan obat yang baru selesai pilot project.

\section{ITOR (Inventory Turn Over Ratio)}

ITOR (Inventory Turn Over Ratio) diperoleh dari total nilai keseluruhan obat yang terdistribusi dibagi dengan total nilai rata-rata persediaan selama setahun. nilai ratarata persediaan dihitung dari jumlah total nilai stok awal dengan total nilai sisa persediaan dibagi dua. Hasil perhitungan ITOR (Inventory Turn Over Ratio) disajikan secara sederhana dalam (Tabel IX).

Nilai standar ITOR yang digunakan menurut ${ }^{12}$ adalah 8-12 kali. Jika dibandingkan 
Tabel IX. ITOR (Inventory Turn Over Ratio)

\begin{tabular}{llccccc}
\hline $\begin{array}{c}\text { Jenis } \\
\text { obat } \\
\text { progra } \\
\mathbf{m}\end{array}$ & $\begin{array}{c}\text { Nilai stok } \\
\text { awal (Rp) }\end{array}$ & $\begin{array}{c}\text { Nilai } \\
\text { persediaan } \\
\mathbf{( R p )}\end{array}$ & $\begin{array}{c}\text { Nilai yang } \\
\text { terdistribusi } \\
\mathbf{( R p})\end{array}$ & $\begin{array}{c}\text { Nilai sisa } \\
\text { persediaan } \\
\mathbf{( R p )}\end{array}$ & $\begin{array}{c}\text { Nilai } \\
\text { rata-rata } \\
\text { persediaa } \\
\mathbf{n}(\mathbf{R p})\end{array}$ & $\begin{array}{c}\text { ITOR } \\
\text { (kali) }\end{array}$ \\
\hline Malaria & 83.704 .506 & 112.487 .786 & 66.947 .636 & 45.540 .150 & 64.622 .328 & \\
Kusta & 133.882 .845 & 190.133 .635 & 94.346 .667 & 95.786 .968 & 114.834 .90 & \\
& & & & & 7 & \\
TB & 1.976 .795 .40 & 3.326 .200 .985 & 2.133 .321 .602 & 1.192 .879 .383 & 1.584 .837$. & \\
& 8 & & & & 396 & 1,15 \\
HIV/AI & 387.658 .857 & 2.164 .379 .418 & 768.779 .977 & 1.395 .599 .441 & 891.629 .14 & \\
DS & & & & & 9 & \\
Total & $\mathbf{2 . 5 8 2 . 0 4 1 . 6 1}$ & $\mathbf{5 . 7 9 3 . 2 0 1 . 8 2 4}$ & $\mathbf{3 . 0 6 3 . 3 9 5 . 8 8 2}$ & $\mathbf{2 . 7 2 9 . 8 0 5 . 9 4 2}$ & $\mathbf{2 . 6 5 5 . 9 2 3 .}$ & \\
& $\mathbf{6}$ & & & & $\mathbf{7 7 9}$ & \\
\hline
\end{tabular}

Tabel X. Sistem Penyimpanan Obat

\begin{tabular}{lcl}
\hline Jenis obat program & Hasil pengamatan & Standar \\
\hline Malaria & + & \\
Kusta & + & Sesuai FIFO/FEFO \\
TB & + & \\
HIV/AIDS & + & \\
\hline
\end{tabular}

Keterangan: (+) : Sesuai FIFO/FEFO; (-) : Tidak sesuai FIFO/FEFO

dengan nilai ITOR hasil penelitian, yaitu 1,15 kali maka belum memenuhi standar. Hal ini menggambarkan bahwa perputaran obat program yang terdistribusi belum efisien. Hasil Penelitian ini belum lebih baik dari hasil penelitian', yaitu 5,77 kali. Hal ini dikarenakan adanya obat dropping dari pusat yang jumlahnya berlebih, penerimaan obat diakhir tahun dan tidak adanya permintaan Kota/ Kabupaten untuk obat tertentu, sehingga akan berpengaruh pada nilai stok obat mati dan nilai obat kadaluarsa.

\section{Sistem penyimpanan obat}

Sistem penyimpanan obat dilakukan melalui pengamatan terhadap sistem penyimpanan obat dilakukan dengan cara mengamati nomor batch dan tanggal kadaluarsa pada obat di rak atau pallet dan SBBK serta tanggal masuk keluarnya obat di kartu stok. Hasil penelitian ini pada (Tabel X) menunjukkan bahwa sistem penyimpanan obat sudah menggunakan sistem FIFO/FEFO. Hasil penelitian ini sudah sesuai dengan standar ${ }^{11}$ dan hasil penelitian ${ }^{22}$, yaitu sesuai FIFO/FEFO. Hal ini menunjukkan sistem penyimpanan obat sudah efektif dan efisien.

\section{Persentase kecocokan jumlah barang nyata dengan kartu stok}

Kecocokan jumlah barang nyata dengan kartu stok diperoleh dari jumlah persediaan terakhir obat yang ada pada kartu stok kemudian dicocokkan dengan jumlah persediaan obat yang ada di rak atau pallet. Hasil penelitian menunjukkan bahwa persentase kecocokan jumlah barang nyata dengan kartu stok (Tabel XI) sudah sesuai $100 \%$, nilai ini sudah sesuai dengan standar yang ditentukan ${ }^{12}$. Hasil penelitian ini lebih baik dari hasil penelitian ${ }^{23}$, yaitu $55,92 \%$. Hal ini menunjukkan bahwa pencatatan kartu stok dan ketelitian petugas dalam mengontrol obat masuk dan keluar sudah efektif dan eifsien. 
Tabel XI. Persentase Kecocokan Jumlah Barang Nyata dengan Kartu Stok

\begin{tabular}{lcc}
\hline \multicolumn{1}{c}{ Jenis obat program } & $\begin{array}{c}\text { Kecocokan antara kartu stok dan } \\
\text { barang }(\%)\end{array}$ & Nilai standar (\%) \\
\hline Malaria & 100 & \\
Kusta & 100 & 100 \\
TB paru & 100 & \\
HIV-AIDS & 100 & \\
\hline
\end{tabular}

\section{Pendukung manajemen perencanaan dan distribusi}

Indikator yang digunakan dalam pendukung manajemen perencanaan dan distribusi adalah manajemen organisasi, penanggung jawab, jumlah sumber daya manusia (SDM), ketersediaan dana dan sistem informasi.

\section{Manajemen organisasi}

Koordinasi pengelolaan obat program di Dinas Kesehatan Provinsi Sulawesi Tenggara dilakukan mulai dari Pusat, Provinsi, Kota/Kabupaten, hal ini sesuai dengan standar manajemen organisasi menurut $^{13}$, yaitu berjenjang. Hasil penelitian ${ }^{22}$ menunjukkan hasil yang sama, yaitu adanya koordinasi secara berjenjang dari Dinas Kesehatan Provinsi, Dinas Kesehatan Kabupaten, Puskesmas.

\section{Penanggung jawab}

Hasil penelitian menunjukkan penanggung jawab pengelolan obat di UPTD Balai Pengelola Farmasi dan Perbekalan Kesehatan adalah seorang apoteker, hal ini sudah sesuai dengan standar yang ditentukan oleh $^{1}$ dan hasil penelitian ${ }^{24}$, yaitu penanggung jawab Instalasi Farmasi adalah seorang apoteker. Penanggung jawab yang memiliki kompetensi dan profesional diperlukan untuk mencapai pengelolaan obat yang baik ${ }^{13}$.

\section{Jumlah Sumber Daya Manusia (SDM)}

Standar jumlah sumber daya manusia yang ditetapkan oleh ${ }^{14}$ adalah $\geq 4$ orang, sedangkan jumlah SDM yang ada di UPTD Balai Pengelola Farmasi dan Perbekalan
Kesehatan adalah 20 orang. Hal ini berarti Jumlah SDM sudah sesuai nilai standar, tetapi dari hasil wawancara ada masukan untuk penambahan tenaga non teknis pengangkut barang dan tenaga informasi dan teknologi. Penelitian ${ }^{10}$ menunjukkan jumlah SDM di Gudang Farmasi Kabupaten Gunung Mas Provinsi Kalimantan Tengah berjumlah 4 orang. Jumlah SDM yang dibutuhkan disesuaikan dengan beban kerja yang ada agar pengelolaan obat yang baik dapat tercapai ${ }^{13}$.

\section{Ketersediaan dana}

Standar ketersediaan dana menurut ${ }^{1}$ adalah tersedia. Hasil penelitan yang diperoleh adalah tersedia dana pengelolaan obat di Dinas Kesehatan Provinsi Sulawesi Tenggara yang berasal dari donor atau pinjaman hibah luar negeri, APBN dan APBD, hal ini sesuai dengan standar. Hasil Penelitian ini sama dengan hasil penelitian ${ }^{7,25}$, yaitu tersedianya dana pengadaan obat dan operasional lainnya. Ketersediaan dana dari berbagai sumber perlu diidentifikasi agar semua sumber dana dapat dikelola dengan baik. Dengan demikian pengelolaan obat yang baik dapat tercapai ${ }^{13}$.

\section{Sistem informasi}

Dinas Kesehatan Provinsi Sulawesi Tenggara sudah menggunakan sistem informasi dalam Pengelolaan data dan pelaporan obat, yaitu E-logistik. sistem informasi dalam pelaporan juga digunakan pada masing-masing program, yaitu sistem pelaporan program malaria disebut Elektronik sistem informasi malaria (E-sismal), program kusta disebut sistem Informasi pelaporan 
kusta (SIPK), program TB disebut TB 13 dan program HIV/AIDS disebut sistem informasi HIV/AIDS (SIHA). Hal ini sudah sesuai dengan standar yang ditentukan, yaitu tersedia sistem informasi ${ }^{1}$. Menurut penelitian Rahmawatie E ( 2015), Sistem Informasi yang telah berfungsi dengan baik dapat membantu dalam mengambil keputusan khususnya dalam perencanaan kebutuhan obat ${ }^{26}$.

\section{Faktor-faktor yang mempengaruhi perencanaan dan distribusi}

Faktor-faktor yang mempengaruhi pengelolaan dan pendistribusian obat program di Dinas Kesehatan Provinsi Sulawesi Tenggara, yaitu organisasi, pencatatan dan pelaporan dan dana operasional.

\section{Organisasi}

Koordinasi antara Washor penanggung jawab program, petugas pengelola rencana kebutuhan obat dan petugas pengelola obat di Dinas Kesehatan Provinsi Sulawesi Tenggara sudah berjalan tetapi belum optimal karena belum terbentuknya Tim Perencana Obat Terpadu (TPOT). Hal ini sama dengan Hasil penelitian $^{27}$ menyebutkan bahwa pada Instalasi Gudang Obat puskesmas gaya baru $\mathrm{V}$ belum memiliki tim yang secara khusus menangani perencanaan obat, sedangkan Menurut hasil penelitian Rumbay (2015) bahwa perencanaan kebutuhan obat yang baik dan tepat akan tercapai jika ada koordinasi dan monitoring yang baik ${ }^{28}$.

\section{Pencatatan dan pelaporan}

Akses pencatatan dan pelaporan Elogistik belum bisa menampilkan laporan ketersediaan obat masing-masing Kota/ Kabupaten sehingga petugas E-logistik tidak bisa melakukan evaluasi ketersediaan obat secara menyeluruh di Provinsi Sulawesi Tengara, selain itu pencatatan dan pelaporan data terkait temuan kasus belum diperbaharui sehingga nantinya akan mempengaruhi kesinambungan. Menurut penelitian Triana $\mathrm{M}$ (2014), pencatatan dan pelaporan yang tidak akurat mengakibatkan perencanaan tidak optimal $^{10}$. Hasil penelitian ${ }^{3}$ menyebutkan bahwa pelaporan obat ARV belum ada kesesuaian sehingga menyulitkan dalam monitor tahap pengelolaan obat ARV.

\section{Dana operasional}

Hasil penelitian menunjukkan bahwa keterbatasan dan atau keterlambatan realisasi dana operasional di UPTD Balai Pengelola Farmasi dan Perbekalan Kesehatan menyebabkan pemeliharaan sarana dan prasarana penyimpanan obat menjadi terhambat sehingga memungkinkan obat menjadi rusak, selain itu dapat menyebabkan penumpukan obat sehingga memungkinkan obat menjadi kadaluarsa. Menumpuknya obat juga menandakan pendistribusian obat tidak berjalan dengan baik, hal ini akan mempengaruhi pelayanan kesehatan di Fasilitas pelayanan kesehatan tingkat dasar. Hasil penelitian ${ }^{29,30}$ menyebutkan bahwa ketersediaan dana operasional dapat mempengaruhi ketersediaan obat.

\section{Saran atau rekomendasi}

Rekomendasi yang diberikan terhadap permasalahan terdapat pada Tabel XII.

\section{KESIMPULAN}

Berdasarkan hasil penelitian di Dinas Kesehatan Provinsi Sulawesi Tenggara dapat disimpulkan ada 8 indikator yang belum memenuhi standar, yaitu ketepatan perencanan $(6,1 \%)$; penyimpangan perencanaan $(5,85 \%)$; tingkat ketersediaan obat (28 bulan); persentase obat kadaluarsa (8,33\%); persentase penyimpangan obat yang didistribusikan (1,9\%); ITOR (1,15 kali); ratarata waktu kekosongan obat (30 hari); persentase stok obat mati (25\%), sedangkan Indikator yang memenuhi standar ada 7, yaitu sistem penataan obat (FIFO/FEFO); kecocokan jumlah barang nyata dengan stok (100\%); organisasi (berjenjang); penanggung jawab (apoteker); jumlah SDM ( $\geq 4$ orang); keuangan dan sistem informasi (tersedia). Faktor-faktor yang mempengaruhi, yaitu 
Tabel XII. Rekomendasi Terhadap Permasalahan yang Terjadi

\begin{tabular}{|c|c|}
\hline Permasalahan & Rekomendasi (instansi) \\
\hline $\begin{array}{l}\text { Perencanaan belum } \\
\text { dilakukan oleh tim } \\
\text { perencana obat terpadu } \\
\text { (TPOT) }\end{array}$ & $\begin{array}{l}\text { Diperlukan kebijakan Kepala Dinas Kesehatan Provinsi untuk } \\
\text { mengeluarkan SK pembentukan tim perencana obat terpadu } \\
\text { (TPOT) (Dinas Kesehatan Provinsi) }\end{array}$ \\
\hline $\begin{array}{l}\text { Obat yang diminta tidak } \\
\text { sesuai dengan yang } \\
\text { diberikan }\end{array}$ & $\begin{array}{l}\text { Perlu dilakukan evaluasi terhadap perencanaan kebutuhan } \\
\text { obat tahun sebelumnya untuk dijadikan landasan perencanaan } \\
\text { obat tahun berikutnya (Dinas Kesehatan Kota/Kabupaten, } \\
\text { Dinas Kesehatan Provinsi dan Kementerian Kesehatan RI) }\end{array}$ \\
\hline $\begin{array}{l}\text { Keterlambatan realisasi } \\
\text { dana operasional. }\end{array}$ & $\begin{array}{l}\text { Perlu koordinasi yang baik dalam pengelolaan dana } \\
\text { operasional (Dinas Kesehatan Provinsi) }\end{array}$ \\
\hline $\begin{array}{l}\text { Adanya obat kadaluarsa }> \\
2 \%\end{array}$ & $\begin{array}{l}\text { Perlu dilakukan evaluasi terhadap perencanaan kebutuhan } \\
\text { obat tahun sebelumnya dan perubahan pola pengobatan } \\
\text { penyakit (Dinas Kesehatan Kota/Kabupaten, Dinas Kesehatan } \\
\text { Provinsi dan Kementerian Kesehatan RI) }\end{array}$ \\
\hline Ada stok obat mati & $\begin{array}{l}\text { Perlu dilakukan evaluasi terhadap perubahan pola pengobatan } \\
\text { dan membuat aturan atau pedoman pengobatan terhadap } \\
\text { perubahan pola pengobatan yang terjadi (Kementerian } \\
\text { Kesehatan RI) }\end{array}$ \\
\hline Adanya stok obat kosong & $\begin{array}{l}\text { Menyediakan dana khusus untuk suatu kondisi tertentu seperti } \\
\text { biaya relokasi dan adanya Wabah atau KLB (Dinas Kesehatan } \\
\text { Kota/Kabupaten, Dinas Kesehatan Provinsi dan Kementerian } \\
\text { Kesehatan RI). }\end{array}$ \\
\hline $\begin{array}{l}\text { Adanya Pencatatan dan } \\
\text { pelaporan temuan kasus } \\
\text { yang belum diperbaharui }\end{array}$ & $\begin{array}{l}\text { Perlu dilakukan pembaharuan pencatatan dan pelaporan } \\
\text { temuan kasus (Dinas Kesehatan Kota/Kabupaten). }\end{array}$ \\
\hline $\begin{array}{l}\text { Dinas Kesehatan Provinsi } \\
\text { belum bisa mengakses } \\
\text { laporan E-Logitik setiap } \\
\text { Dinas Kesehatan Kota/ } \\
\text { Kabupaten. }\end{array}$ & $\begin{array}{l}\text { Perlu dilakukan pembaharuan sistem informasi E-Logistik } \\
\text { (Kementerian Kesehatan RI). }\end{array}$ \\
\hline
\end{tabular}

koordinasi yang belum optimal; pencatatan dan pelaporan belum diperbaharui dan keterbatasan dan atau keterlambatan realisasi dana operasional.

\section{UCAPAN TERIMAKASIH}

Ucapan terimakasih kepada Badan Pengembangan dan Pemberdayaan SDM Kesehatan, Kementrian Kesehatan Republik Indonesia sebagai pemberi dana pada penelitian ini.

\section{DAFTAR PUSTAKA}

1. Direktorat Jendral Pengendalian Penyakit dan Penyehatan Lingkungan.
Panduan Pengelolaan Logistik Program Pengendalian Tuberkulosis. Jakarta: Kementerian Kesehatan RI; 2014.

2. Quick JD., Ranking J., Laing R. Managing Access to Medicines and Health Technologies. 3rd ed. USA: Management Sciences for Health; 2012.

3. Yuniar Y., Syaripuddin M., Isakh BM. Manajemen Logistik Obat Antiretroviral di Indonesia (Logistic Management of Antiretrovirals in Indonesia). Buletin Penelitian Sistem Kesehatan. 2014;17(2):125-134.

4. Wati W., Fudholi A., Pamudji G. Evaluasi 
Pengelolaan obat dan strategi perbaikan dengan metode hanlon di Instalasi Farmasi Rumah Sakit Tahun 2012. Jurnal Manajemen dan Pelayanan Farmasi. 2013;3(4):283-290.

5. Ihsan S., Amir SA., Sahid M. Evaluasi Pengelolaan Obat di Instalasi Farmasi Rumah Sakit Umum Daerah Kabupaten Muna Tahun 2014. Pharmauho. 2014;1(2):23-28.

6. Sasongko H., Fudholi A., Satibi. Evaluasi Distribusi dan Penggunaan Obat Pasien Rawat Jalan di Rumah Sakit Ortopedi. Jurnal Manajemen dan Pelayanan Farmasi. 2014;4(2):99-104.

7. Mahdiyani U., Wiedyaningsih C., Endarti D. Evaluasi Pengelolaan Obat Tahap Perencanaan dan Pengadaan di RSUD Muntilan Tahun 2015-2016. Jurnal Manajemen dan Pelayanan Farmasi. 2018;8(1):24-31.

8. Silvania A., Hakim L., Satibi. Evaluasi Kesesuaian Antara Perencanaan dan Realisasi Penerimaan Obat di Puskesmas Rawat Inap Se-Kabupaten Sleman Tahun 2008-2010. Jurnal Manajemen dan Pelayanan Kefarmasian. 2012;2(2):90-94.

9. Djatmiko M. Evaluasi Sistem Pengelolaan Obat Instalasi Perbekalan Farmasi Dinas Kesehatan Kota Semarang tahun 2007. Jurnal Ilmu Farmasi dan Farmasi Klinik. 2009;6(1):1-6.

10. Triana M., Suryawati C., Sriyatmi A. Evaluasi Perencanaan Obat Pelayanan Kesehatan Dasar (PKD) di Gudang Farmasi Kabupaten Gunung Mas Provinsi Kalimantan Tengah. Jurnal Manajemen Kesehatan Indonesia. 2014;2(1):44-51.

11. Direktorat Bina Obat Publik dan Perbekalan Kesehatan. Materi Pelatihan Manajemen Kefarmasian di Instalasi Farmasi Kabupaten/ Kota. Jakarta: Kementerian Kesehatan RI; 2010.

12. Pudjaningsih D. Pengembangan Indikator Efisiensi Pengelolaan Obat di Farmasi Rumah Sakit. Tesis, Magister
Manajemen Rumah Sakit, Universitas Gadjah Mada. Yogyakarta. 1996.

13. Direktorat Jendral Pengendalian Penyakit dan Penyehatan Lingkungan. Panduan Pengelolaan Logistik Program Pengendalian TBC. Jakarta: Kementrian Kesehatan RI; 2010.

14. Dirjen Oblik dan Perbekkes. Rencana Aksi Kegiatan Dit. Bina Oblik Dan Perbekkes 2015-2019. Jakarta: Kementrian Kesehatan RI; 2015.

15. Febreani SH., Chalidyanto D. Pengelolaan Sediaan Obat Pada Logistik Farmasi Rumah Sakit Umum Tipe B di Jawa Timur. Jurnal Administrasi Kesehatan Indonesia. 2016;4(2):136-145.

16. Rohmani S., Fudholi A. Analisis Faktor Internal-Eksternal Terhadap Pengelolaan Obat di Instalasi Farmasi RSUD DR. Moewardi Surakarta. Journal of Pharmaceutical Science and Clinical Research. 2016;1:10-20.

17. Razak A., Pamudji G., Harsono M. Analisis Efisiensi Pengelolaan Obat Pada Tahap Distribusi dan Penggunaan di Puskesmas. Jurnal Manajemen dan Pelayanan Kefarmasian. 2012;2(3):186194.

18. Waluyo YW., Athiyah U., Rochmah TN. District Pharmacy Installation (Study in Southern Papua Area). Jurnal Ilmu Kefarmasian Indonesia. 2015;13(7):94-101.

19. Akbar NH., Kartinah N., Wijaya C. Analisis Manajemen Penyimpanan Obat di Puskemas Se-Kota Banjar Baru. Jurnal Manajemen dan Pelayanan Kefarmasian. 2016;6(4):255-260.

20. Sanjaya GY., Hidayat AW. Pemantauan Obat dan Perbekalan Kesehatan di Indonesia: Tantangan dan Pengembangannya. Jurnal Manajemen Farmasi. 2016;6(2):159-168.

21. Mellen RC., Pudjirahardjo WJ. Faktor Penyebab dan Kerugian Akibat Stock out dan Stagnant Obat di Unit Logistik RSU Haji Surabaya. Jurnal Administrasi Kesehatan Indonesia. 2013;1(1):99-107. 
22. Mangindra., darmawansyah., Nuryani., Balqis. Analisis Pengelolaan Obat di Puskesmas Kampala Kecamatan SinjaiI Timur Kabupaten Sinjai Tahun 2011. Jurnal AKK. 2012;1(1):31-40.

23. Fakhriadi A., Pudjaningsih D., Farmasi M. Analisis Pengelolaan Obat di Instalasi Farmasi Rumah Sakit PKU Muhammadiyah Temanggung Tahun 2006, 2007 dan 2008. Jurnal Manajemen dan Pelayanan Farmasi. 2011;1(2):94-102.

24. Malinggas NER., Posangi J., Soleman T. Analisis Manajemen Logistik Obat di Instalasi Farmasi Rumah Sakit Umum Daerah DR Sam Ratulangi Tondano. Jurnal Ilmu Kesehatan Masyarakat Unstrat. 2015;5(2b):448-460.

25. Safriantini D., Ainy A., Mutahar R. Analisis Perencanaan dan Pengadaan Obat di Puskesmas Pembina Palembang. Jurnal Ilmu Kesehatan Masyarakat. 2011;2(1):30-38.

26. Rahmawatie E., Santosa S. Sistem Informasi Perencanaan Pengadaan
Obat di Dinas Kesehatan Kabupaten Boyolali. Jurnal Pseudocode. 2015;2(1):4552.

27. Indriawan I., Wahyudi WT., Rahayuningsih A. Analisis Pengelolaan Obat di Puskesmas Gaya Baru V Kecamatan Bandar Surabaya Kabupaten Lampung Tengah. Journal kesehatan Holistik. 2014;8(1):1-6.

28. Rumbay IN., Kandou GD., Soleman T. Analisis Perencanaan Obat di Dinas Kesehatan Kabupat en Minahasa Tenggara. Jurnal Ilmu Kesehatan Masyarakat Unstrat. 2015;5(2):469-478.

29. Elamin EI., Ibrahim MIM., Yousif MAE. Availability of Essential Medicines in Sudan. Sudanese Journal of Public Health. 2010;5(1):32-37.

30. Nursyandi A., Hasanbasri M. Ketersediaan Obat Esensial Pada Sarana Kesehatan di Kabupaten Bangka Barat. Jurnal Kebijakan Kesehatan Indonesia. 2012;1(3):125-133. 